UDC 621.923

TECHNICAL SCIENCES AND TECHNOLOGIES

DOI: $10.25140 / 2411-5363-2018-2(12)-86-93$

\author{
Oleksandr Lytvyn, Dmytro Kalchenko
}

\title{
INVESTIGATION OF THE PROCESS OF DOUBLE-SIDED GRINDING OF TORCHES OF PUSHERS WITH DIFFERENT DIAMETRERS
}

Urgency of the research. In machine tools, automotive, agricultural engineering, manufacturing, where it is necessary to ensure high accuracy of surfaces of parts with different diameters of faces, it is required to adhere to high requirements for the quality of geometric sizes, roughness and accuracy of molding.

Target setting. Grinding of end surfaces of parts with different diameters of faces, is carried out on two-sided end-grinding machines. The specific gravity of grinding in the total complexity of mechanical processing is constantly increasing and at the present stage it is about $30 \%$ in the machine tool industry, in the automotive industry more than $38 \%$ of the total complexity of processing.

Actual scientific researches and issues analysis. On the two-sided end-grinding machines of the Saturn company (Germany) the processing of round ends of parts is done with a circular feed to the processing area. Abrasive wheels are used without calibrating plots, which requires a lot of processing to obtain the required precision, which reduces the productivity of grinding. The disadvantage of the method is that the processing of parts with different face diameters is not considered.

Uninvestigated parts of general matters defining. It is necessary to improve the processing efficiency of parts by developing the methods of two-sided polishing of the ends of pushers with different diameters oriented grinding wheels with and without calibrating sections, and also the rotation or without rotation of the workpiece on the calibration section, at least one revolution.

The research objective. Improving the accuracy of finishing the end surfaces of parts of various diameters with grinding wheels, is achieved by the fact that the shaping of the ends of the smaller diameter is performed by the maximum diameter of the flat end of one circle, and the shaping of the end face of a larger diameter - the calibration section of the second circle, the length of which is equal to the diameter of the larger end and filled with diamond pencil, which moves along a radius, which coincides with the radius of the location of the axes of the parts in the feed drum.

The statement of basic materials. In order to ensure the processing of parts in one pass and the necessary precision of processing, in large-scale and mass production, a grinding method oriented circles with calibrated sections with one-sided arrangement of ends of one diameter is used. The calibration sections are then made of different lengths, depending on the diameter, respectively, larger and smaller.

Conclusions. The universal method of practical application of model of accuracy of shaping of ends of parts of different diameters, oriented grinding circles with and without calibration plots has been suggested. The presented method simplifies the grinding of the grinding wheel. It does not require special editing and allows to use regular editing.

Keywords: grinding; ends of different diameters; pushers; oriented grinding wheels; calibration sections.

Fig.: 3. References: 10.

Urgency of the research. In machine tools, automotive, agricultural engineering, manufacturing, where it is necessary to ensure high accuracy of surfaces of parts with different diameters of faces, it is required to adhere to high requirements for the quality of geometric sizes, roughness and accuracy of molding. Moreover, further intensification of grinding processes is impossible without a rational accounting of the general influence of the conditions of mechanical cutting and the properties of the grinding tool and the workpiece, which reduces the power and thermal factors, increases the speed of material removal, improve the quality of the treated surface.

Target setting. Grinding of end surfaces of parts with different diameters of faces, is carried out on two-sided end-grinding machines. The specific gravity of grinding in the total complexity of mechanical processing is constantly increasing and at the present stage it is about $30 \%$ in the machine tool industry, in the automotive industry more than $38 \%$ of the total complexity of processing [8].

Actual scientific researches and issues analysis. On the two-sided end-grinding machines of the Saturn company (Germany) [1] the processing of round ends of parts is done with a circular feed to the processing area. Abrasive wheels are used without calibrating plots, which requires a lot of processing to obtain the required precision, which reduces the productivity of grinding. it is known the method of simultaneous grinding of two ends of cylindrical parts [2]. The disadvantage of the method is that the processing of parts with different face diameters is not considered.

Significant influence on the formation of the relief of the working surface of the grinding wheel provide cutting modes, geometric parameters, physical and mechanical properties of the tool and the material being processed. It is known that when working on a grinding wheel in the mode of predominant blunting on the tops of grains there are areas of wear, and when circles work in the self-tuning mode such areas are almost not observed [9, etc.].

(с) Литвин О. О., Кальченко Д. В., 2018 
TECHNICAL SCIENCES AND TECHNOLOGIES

Uninvestigated parts of general metters defining. It is necessary to improve the processing efficiency of parts by developing the methods of two-sided polishing of the ends of pushers with different diameters oriented grinding wheels with and without calibrating sections, and also the rotation or without rotation of the workpiece on the calibration section, at least one revolution.

The research objective. Improving the accuracy of finishing the end surfaces of parts of various diameters with grinding wheels, is achieved by the fact that the shaping of the ends of the smaller diameter is performed by the maximum diameter of the flat end of one circle, and the shaping of the end face of a larger diameter - the calibration section of the second circle, the length of which is equal to the diameter of the larger end and filled with diamond pencil, which moves along a radius, which coincides with the radius of the location of the axes of the parts in the feed drum. This method simplifies the grinding of the grinding wheel. It does not require special editing, allows you to use regular editing. It would also be advisable to develop a model of processing performance of each end of the component, total productivity, techniques of theoretical and experimental studies of processing at each end of the productivity of the grinding, power and cutting forces, which will increase the efficiency of the evaluation for new ways of grinding ends.

The statement of basic materials. Firstly, the size of the admission, which is removed when grinding, is determined. If the propensity is small, then it is advisable to handle the oriented grinding wheels without calibration areas [3], and without rotation of the part around its own axis. If more precision is required, it is used a rotating part method. In the case of the processing of parts with the removal of large allowances, the possibility of processing with oriented grinding wheels without calibrated areas with one-sided arrangement of ends of one diameter [4] is checked. This processing option is chosen if the error on the ends of the larger diameter is no more than permissible. In order to ensure the processing of parts in one pass and the necessary precision of processing, in large-scale and mass production, a grinding method [5-9] oriented circles with calibrated sections with one-sided arrangement of ends of one diameter is used. The calibration sections are then made of different lengths, depending on the diameter, respectively larger and smaller. The calculation of the accuracy of the shaping of parts is carried out according to the program of a universal model of precision shaping of parts with ends of different diameters.

When the billets 3 are fed into the machining area along the guide with the required clearance $\Delta \delta$, the workpiece 3 is shifted axially by a magnitude $\Delta \delta$, which increases the removable allowance on one end and reduces it to the second, which results in various productivity, cutting forces and wear of the wheels.

The torque M, which rotates the workpiece 3 (Fig. 1) during processing, is determined by the formula [10]

$$
M=2\left(R_{\max }-R_{\min }\right) \cdot P_{z},
$$

where $P_{z}$ - the value of the tangential force of cutting on the maximum $R_{\max }$ and minimum $R_{\text {min }}$ touch radius of the grinding wheel 1 and the parts 3 with a diameter $\mathrm{d}$.

The analysis of formula (1) shows that when the part enters the processing area and touches the diameter of the circle, which is equal to $R_{v}-L_{\kappa}$ (pic 1), $L_{\kappa}=\mathrm{d}$ part in this case $R_{\min }=$ 0 , and a circle, due to cutting forces $P_{z}$, begins to rotate the part clockwise with a speed approaching the speed of the grinding wheel, with a decrease in the coefficient of slipping the part, there is a transient process in which there is no time to withdraw the allowance and the intense wear of the circle begins. In the process of moving the workpiece 3 feeder drum 1, the speed of rotation of the workpiece gradually decreases and when the contact includes the entire face and the radius touching details the transition process is over, there is a torque (1) that rotates clockwise (Fig. 1). When the part is exited from the roughing zone on the calibration section of the cutting force $P_{z}$ are decreasing, as the contact occurs along the line, and with a 
TECHNICAL SCIENCES AND TECHNOLOGIES small depth of grinding, and at the exit of the end of the part for the outer diameter of the circle $R_{v}, R_{\text {min }}$ gradually decreases to 0 , the direction of rotation is changing and the part begins to rotate anticlockwise, there is a transient process due to the overclocking of the part by the maximum diameter of the circle $R_{\max }=R_{V}$ at the end of the calibration area with low intensity (1). The experimental study of the process of rotation of the workpiece by cutting forces for double-faceted grinding has been first performed by the author [5], where the speed of the piston pin was measured by a digital laser contactless tachometer HS2234.

The torque M, which rotates pusher 3 (Fig. 1) during processing, is determined by the formula.

$$
M=\left(R_{\max D}-R_{\min D}\right) \cdot P_{z D}-\left(P_{n D}-P_{n d}\right) \cdot f \cdot R_{t}+\left(R_{\max d}-R_{\min d}\right) \cdot P_{z d},
$$

where $P_{z D}$ - the value of the tangential force of cutting at the maximum $R_{\max D}$ and minimum $R_{\min D}$ touch radius of the grinding wheel 2 and the part 3 'in diameter $\mathrm{D} ; \mathrm{P}_{\mathrm{nD}}, \mathrm{P}_{\mathrm{nd}}-$ normal components of the cutting force on the larger and smaller ends; $f$-coefficient of friction on the end of the drum hub; $R_{t}$ - radius of friction of the pusher on the hub of the drum; $P_{z d}-$ the value of the tangential cutting force at the maximum $R_{\max d}$ and minimum $R_{\min d}$ touch radius of the grinding wheel 1 and the part 3 with diameter $d$.

The analysis of formula (2) shows that the larger diameter D first enters the processing area and touches the diameter of the circle 1 , which is equal to $R_{v}-L_{k}, L_{k}=\mathrm{D}$ and circle 1 , due to cutting forces $P_{z D}$, begins to rotate the part anticlockwise at a speed that is approaching the speed of the grinding wheel, a transient process appeares. When moving the feed drum by a value equal to D / 2-d / 2, processing of the end face of a smaller diameter, on which the torque and the normal component appear $\mathrm{P}_{\mathrm{nd}}(3)$. In the process of moving the part by the drum, when the contact is the end of the part $\mathrm{D}$, the radiuses $R_{\max }, R_{\min }$ touching parts, the transition process is over (Fig. 1), and there is a torque M (3), and at the output of the larger end of the diameter of the part for the outer diameter of the circle $R_{v}=R_{\max }, R_{\min }$ gradually decreases to 0 , the direction of rotation changes, there is a transient process due to the overclocking of the part with a larger diameter of the circle $R_{v}$.

Since $\mathrm{P}_{\mathrm{n}} \leq 3 P_{z}$, the coefficient of friction $f \leq 0.15-0.2, R_{t} \leq D / 2$, the torque calculated by the formula (3) for the maximum values of $\mathrm{P}_{\mathrm{n}}, f, R_{t}$ is greater than the friction moment, therefore the part will always be rotated.

The developed 3D model first determines the overall performance Qs of the processing of two round ends, for example: pushers, roller bearings and other parts, depending on the processing coordinate $\theta \mathrm{b}$ along the entire length of the contact line L. It is equal

$$
Q_{s}=Q_{l}+Q_{p},
$$

where $Q_{l}$ and $Q_{p}$ - the processing performance of the left and right ends of the parts.

The left-hand side, in the coordinate system of the part (Fig. 1.2) has a coordinate $\mathrm{Z}_{\mathrm{d}}=-\frac{H}{2}$, and the right $\mathrm{Z}_{\mathrm{d}}=\frac{H}{2}$, where $\mathrm{H}$ is the length of the part.

The number of parts $\mathrm{m}$, which are simultaneously machined on the machine, is determined by the formula

$$
m=\frac{L}{d}+\boldsymbol{B}_{p}
$$

where $\mathrm{L}=\mathrm{Rb} \theta \mathrm{b} 2$ - the length of the contact arc on the radius $\mathrm{Rb}$ of the feed drum 1, parts 3 with circles 1,2 at the angle $\theta b 2 ; \theta b 1, \theta b 2$ - the angles of the position of the part at the begin- 
TECHNICAL SCIENCES AND TECHNOLOGIES

ning of the processing and the points $\mathrm{n}$; $\mathrm{d}$ - outer diameter of the part $3 ; \mathrm{Bp}$ - the distance between the parts on the radius of the feed drum Rb. Formation of the end face of a smaller diameter is performed by the maximum diameter of the flat end of one circle, and the shaping of the face of the larger diameter - the calibration section of the second circle, the length of which is equal to the diameter of the larger end and filled with a diamond pencil which axis moves along the radius, that coincides with the radius of the location of the axes of the parts in the feed drum.

In fig. 1 positions are as follows: 1 - the product feed drum, 2 - the prism, 3 - the workpiece, 4, 5 - grinding wheels, 6, 7 - grinding wheels, 8 - a device for fixing the ends of grinding wheels, 9 - a spherical hinge relative to which there is a turn of circles, 10 - a calibration section of a grinding wheel that handles the ends of larger diameters.

The scheme of the process of bilateral sanding of the ends of the pusher gas distributing mechanisms of internal combustion engines is shown in Fig. 1, where the workpieces 3 are installed in the prisms 2 of the product feed drum 1, are treated with grinding wheels 4,5 , which are rotated to the optimal angles with the grinding wheels 6,7 . The rotation of the grinding wheels 4,5 at the angles $\psi$ and $\varphi$ takes place relative to the spherical hinges 9.

The grinding tubes, together with the circles, orient at the angles $\psi$ in the vertical plane and at the angles $\varphi$ - in the horizontal. In the process of grinding, the parts are moved to a narrowing area.

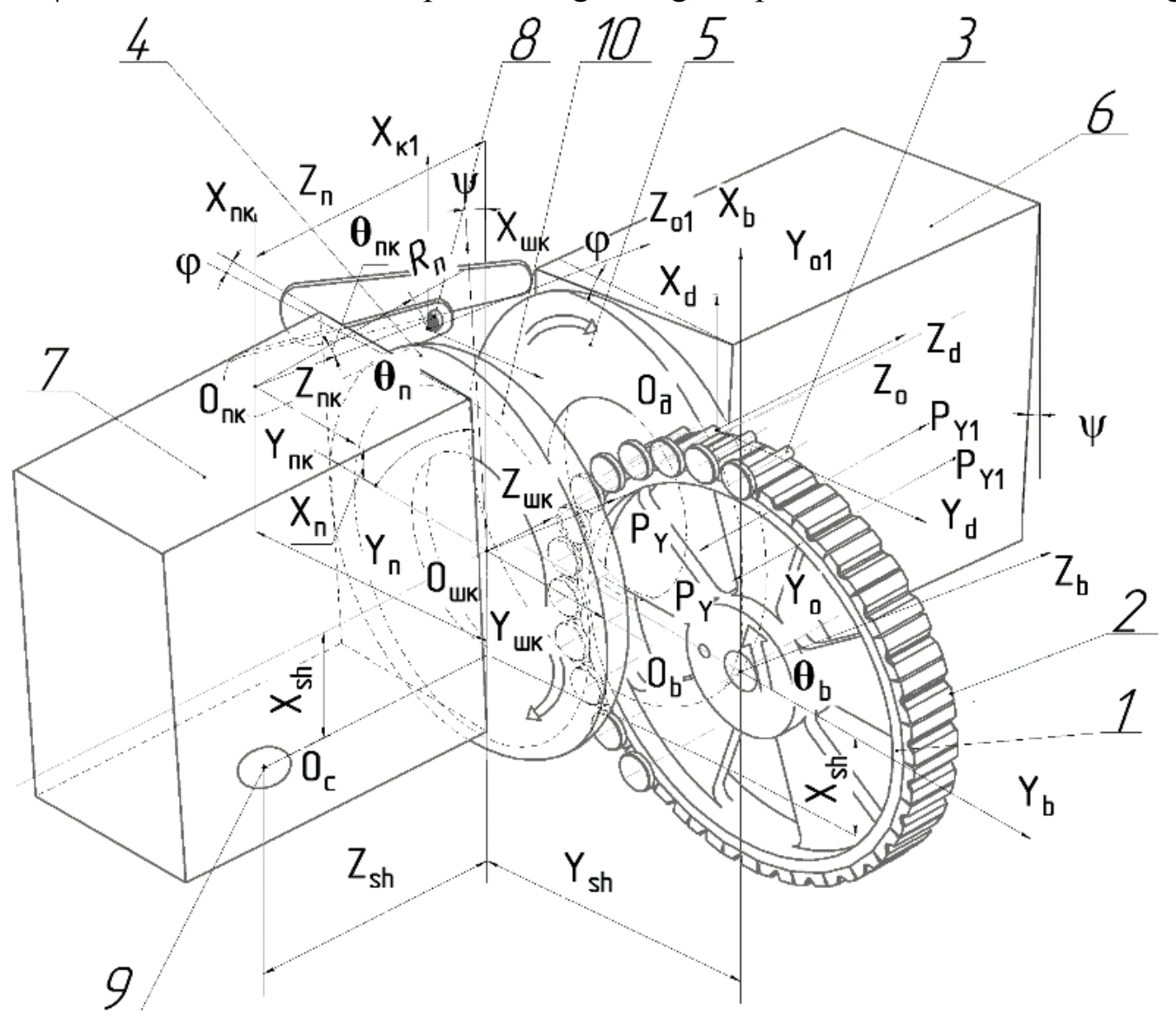

Fig. 1. The scheme of processing the ends of pushers, which rotate and do not rotate during processing

Also, experimental research was carried out on the powers and forces of the pusher cutting according to the coordinate of processing $\theta b$ with different end faces diameters. Grinding is carried out in a new developed way (Fig. 2).

Fig. 3 shows a graph of the power and cutting forces for the coordinate of the processing $\theta \mathrm{b}$ on the two ends of one pusher. The power is shown by curves 1 and 2, and the forces of cutting are curves 5 and 6 . 


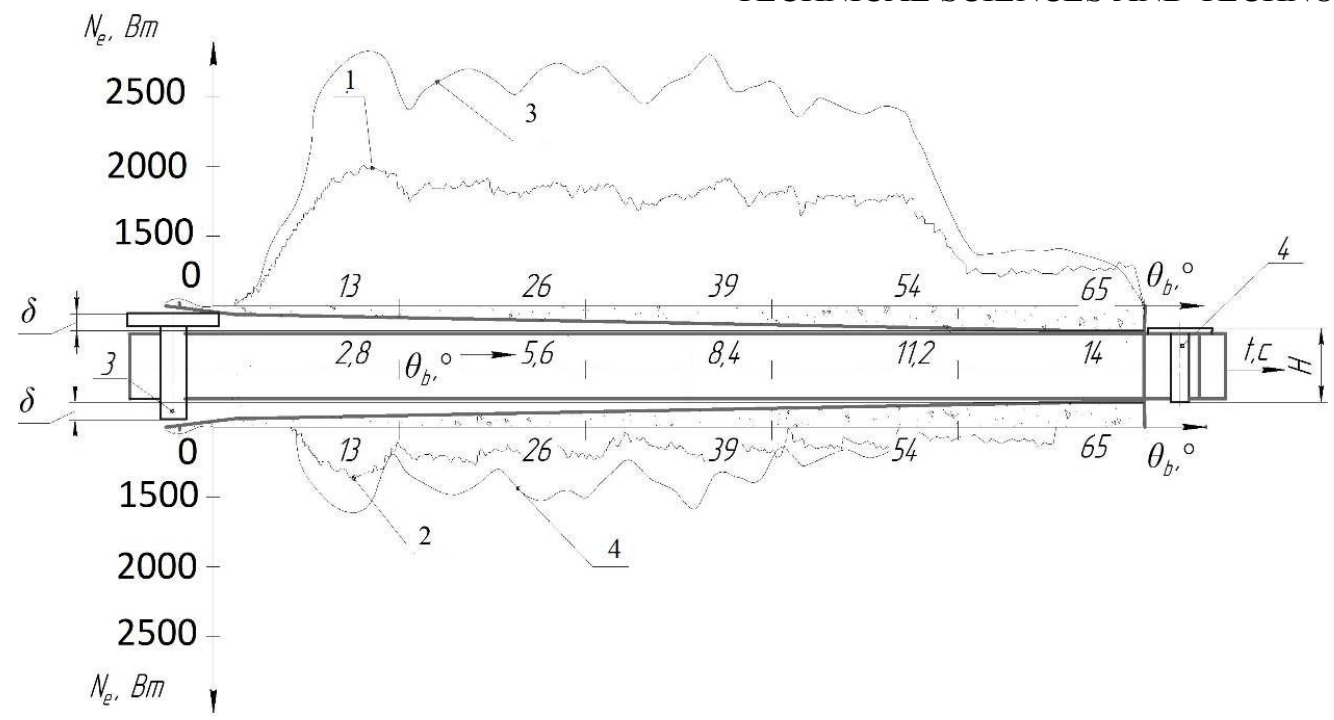

Fig. 2. Active power and cutting forces by coordinate of processing $\theta b$ on two ends of one pusher

Fig. 2 shows a graph of the power and cutting forces of the coordinate of processing $\theta \mathrm{b}$ on the two ends of one pusher. The power is shown in curves 1 and 2, and the cutting forces are curves 3 and 4 . When processing the end of the part, the power is gradually increases until the part completely goes into the roughing area, and then the power value has a practically stable value, since the same tolerance is removed uniformly along the arc of processing, then there is a decline in power, as the part goes into processing by calibrating sections, and at the end the output of the part from the calibration section.

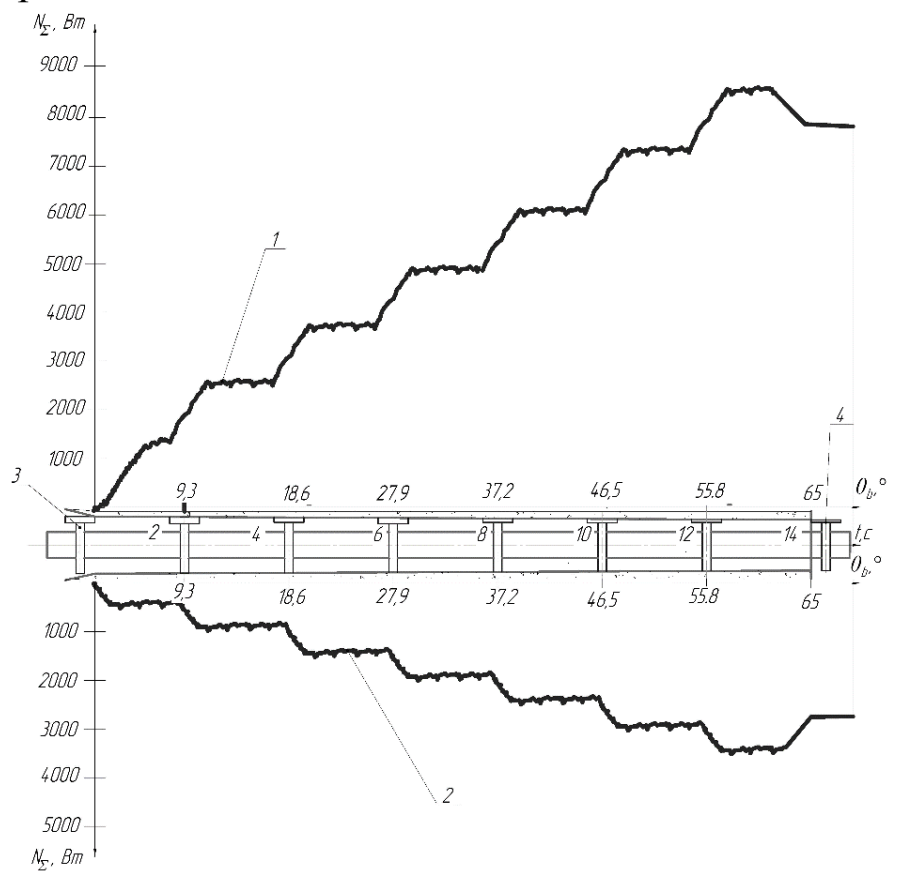

Fig. 3. Total active power, on two ends with continuous supply of pushers to the processing area

In Fig. 3 we show the total power at the coordinate of the processing $\theta b$, the capacity of 1,2 on the two ends, with the continuous supply of pushers 3 to the processing area. The maximum value of total power will be at the point where the calibration area begins, then it begins to decrease by magnitude, the pusher is treated with a calibrating area. When the pusher is released from the calibration area, the following rough pusher is fed into the processing zone. 
TECHNICAL SCIENCES AND TECHNOLOGIES

As it can be seen from the figure, the first pusher enters the big end, this leads to an increase in power, the smaller diameter begins processing with a delay on the difference in radiuses.

Conclusion. The universal method of practical application of model of accuracy of shaping of ends of parts of different diameters, oriented grinding circles with and without calibration plots has been suggested. The presented method simplifies the grinding of the grinding wheel. It does not require special editing and allows to use regular editing.

The model, which allows to determine the torque from the cutting forces when grinding cylindrical round parts of different diameter of the ends, has been developed. The model describes the mechanism of occurrence of the transition process at the input of the part in the processing area, stabilization of the process and the output of the part from the processing area. With the help of this model it is possible to perform the analysis of the accuracy of the shaping of the part when leaving the processing area.

The 3D model of total productivity has been developed and the general method of theoretical and experimental research of specific coordinate processing on each end, and general: grinding productivity, power and cutting forces, which will allow to create new highly effective methods of grinding.

\section{References}

1. Junker, E. (2005). Saturn End-grinding with twin grinding wheels: Journal for Junkermaschinen customers. Nordrash, Germany [in English].

2. Grabchenko, A. I., Kalchenko, V. I. \& Kalchenko, V. V. (2015). Shlifovanie so skreshchivayushchimisya osyami instrumenta i detali [Grinding with cross-axis tool and detail]. (2nd. ed.). Chernihiv: CSTU [in Russian].

3. Kalchenko, V. V. \& Zhadan, O. V (2005). Declarative Patent of Ukraine for invention (utility model), № 10636B24VMK15.Sposib odnochasnogo shlifuvannya dvokh tortsiv tsilindrichnikh detaley [Method of simultaneous grinding of two ends of cylindrical parts]. № u200505125; stated on May 30, 05; has published on Nov 15, 05[in Ukrainian].

4. Venzheha, V. I. (2009). Pidvyshchennia efektyvnosti shlifuvannia tortsiv pry skhreshchenykh osiakh detali ta kruha $\mathrm{z}$ kalibruvalnoiu diliankoiu [Improving the effectiveness of grinding end faces in crossed axes parts and circles with a calibration area].Canditate's thesis. Kharkiv[in Ukrainian].

5. Kalchenko, V. I., Kalchenko, V. V., Slednikova, O. S. \& Kalchenko, D. V. (2016). Doslidzhennia protsesu shlifuvannia tortsiv oriientovanykh detalei profilovanymy kruhamy [Investigation of the process of grinding of ends of oriented details with profiled circles]. Visnyk Cherkaskoho derzhavnoho tekhnolohichnoho universytetu. Seriia: Tekhnichni nauky - Bulletin of Cherkasy State Technological University. Series: Engineering, 4, 72-82 [in Ukrainian].

6. Kalchenko, V. I., Kalchenko, V. V., Sliednikova, O. S. \& Kalchenko, D. V. (2016). Teoretychne ta eksperymentalne doslidzhennia protsesiv znattia prypusku, znosu kruhiv, tochnosti formoutvorennia ta teplonapruzhennosti pid chas shlifuvannia tortsiv detalei [Theoretical and experimental research of the processes of the knowledge of the letdown, wear of circles, the accuracy of forming and heat stress during the grinding of the ends of the parts]. Visnyk Chernihivskoho Natsionalnoho Tekhnolohichnoho Universytetu. Seriia: Tekhnichni nauky - Bulletin of the Chernihiv National Technological University. Series: Engineering, 4 (6), 25-34 [in Ukrainian].

7. Filimonov, L. N. (1985). Ploskoe shlifovanie [Flat grinding]. Lviv: Mechanical Engineering [in Russian].

8. Lavrinenko, V. I., Shepelev, A. A. \& Dubrova, A. E. (2003). Konkurentosposobnost i tekhnicheskiy uroven shlifovalnykh krugov iz STM [Competitiveness and technical level of sliifalvalnyh circles from STM]. Vysoki tekhnolohii v mashynobuduvanni - High technologies in mechanical engineering, 1 (6), 179-186 [in Russian].

9. Lurie, G. B. (1970). Shlifovanie metallov [Grinding of metals]. Moscow: Science [in Russian].

10. Eroshenko, A. M. \& Kalchenko, D. V. (2018). Doslidzhennia protsesu dvostoronnoho shlifuvannia tortsivtsylindrychnykh detalei oriientovanymy kruhamy z kalibruiuchymy diliankamy. Kompleksne zabezpechennia yakosti tekhnolohichnykh protsesiv ta system [Investigation of the process of two-sided grinding of ends of cylindrical parts with orientated circles with calibrated sections. Integrated assurance of the quality of technological processes and systems]. (Vols. 1) (pp. 183-185). Chernihiv [in Ukrainian]. 


\section{References (in language original)}

1. Saturn. Торцевое шлифование спаренными шлифовальными кругами: [Журнал для клиентов фирмы «Junkermaschinen»] / Erwin Junker: Maschinenfabric Gmbh, Junkerstraße 2. Postfach 25. D 77787. - Nordrash, Germany, 2005 - 8 c.

2. Грабченко А. И. Шлифование со скрещивающимися осями инструмента и детали : монография / А. И. Грабченко, В. И. Кальченко, В. В. Кальченко. - Издание 2-е, дополненное. Чернигов : ЧНТУ, 2015. - 504 с.

3. Деклараційний патент України на винахід (корисну модель), №10636В24ВМКл5/04. Спосіб одночасного шліфування двох торців циліндричних деталей / Кальченко В. В., Жадан О. В. ; заявник та патентовласник Кальченко В. В., Жадан О. В. - № u200505125 ; заявл. 30.05.05; опубл. 15.11.05, Бюл. № 1.

4. Венжега B. I. Підвищення ефективності шліфування торців при схрещених осях деталі та круга з калібрувальною ділянкою : дис. ... канд. техн. наук : спец. 05.03 .01 / В. І. Венжега ; Харківський політехнічний інститут. - Х., 2009. - 214 с.

5. Дослідження процесу шліфування торців орієнтованих деталей профільованими кругами / В. І. Кальченко, В. В. Кальченко, О. С. Слєднікова // Вісник Черкаського державного технологічного університету. Серія: Технічні науки. -2016. - № 4. - С. 72-82.

6. Теоретичне та експериментальне дослідження процесів знаття припуску, зносу кругів, точності формоутворення та теплонапруженності під час шліфування торців деталей / В. І. Кальченко, В. І. Венжега, О. С. Слєднікова, Д. В. Кальченко // Вісник Чернігівського національного технологічного університету. Серія: Технічні науки: науковий журнал. - 2016. - № 4 (6). - С. 25-34.

7. Филимонов Л. Н. Плоское шлифование / Л. Н. Филимонов. - Л. : Машиностроение, 1985. - $109 \mathrm{c}$.

8. Лавриненко В. И. Конкурентоспособность и технический уровень шлифовальных кругов из СТМ / В. И. Лавриненко, А. А. Шепелев, А. Е. Дуброва // Високі технології в машинобудуванні. - Харків, 2003. - Вип. 1(6). - С. 179-186.

9. Лурье Г. Б. Шлифование металлов / Г. Б. Лурье. - М. : Наука, 1970. - 172 с.

10. Єрошенко А. М. Дослідження процесу двостороннього шліфування торців циліндричних деталей орієнтованими кругами з калібруючими ділянками / А. М. Срошенко, Д. В. Кальченко // Комплексне забезпечення якості технологічних процесів та систем: матеріали конференції. - Чернігів, 2018. - T. 1. - С. 183-185.

УДК 621.923

\section{Олександр Литвин, Дмитро Кальченко \\ ДОСЛІДЖЕННЯ ПРОЦЕСУ ДВОСТОРОННЬОГО ШЛІФУВАННЯ ТОРЦІВ РІЗНОГО ДІАМЕТРА}

Актуальність теми дослідження. У верстатобудуванні, автомобілебудуванні, сільськогосподарському машинобудуванні, виробництвах, де необхідне забезпечення високої точності поверхонь деталей з різними діаметрами торчів, потрібно дотримуватися високих вимог до якості, що висуваються до геометричних розмірів, шорсткості та точності формоутворення.

Постановка проблеми. Шліфування торцевих поверхонь деталей з різними діаметрами ториів, здійснюються на двосторонніх ториешліфувальних верстатах. Питома вага иліфування в загальній трудомісткості механічної обробки постійно зростає і на сучасному етапі становить в верстатобудівної промисловості близько $30 \%$, в автомобільній промисловості понад 38 \% загальної трудомісткості обробки.

Аналіз останніх досліджень і публікацій. На двосторонніх торчешліфувальних верстатах фірми Sатитп (Німеччина) виконусться обробка круглих ториів деталей із круговою подачею в зону обробки. Використовуються абразивні круги без калібруючих ділянок, що вимагає багатопрохідну обробку для отримання необхідної точності, що знижує продуктивність шліфування. Недоліком способу є те, щчо не розглядається обробка деталей із різними діаметрами ториів.

Виділення недосліджених частин загальної проблеми. Потрібно здійснити підвищення ефективності обробки деталей, завдяки вдосконаленню способів двостороннього шліфування ториів штовхачів із різними діаметрами орієнтованими профільованими шліфувальними кругами з калібруючими ділянками та без них, а також обертання чи не обертання оброблювальної деталі на калібруючій діляниі, не менше одного оберту.

Постановка завдання. Підвищення точності обробки кінцевих поверхонь деталей різного діаметра зі шліфувальними кругами досягається тим, що формування кінців меншого діаметра здійснюється за допомогою максимального діаметра плоского кіния одного кола, а формування ториева поверхня більшого діаметра - калібрувальна секиія другого кола, довжина якої дорівнює діаметру більшого кіния й наповнена алмазним олівцем, який рухається вздовж радіуса, який збігається з радіусом розташування осі частин у подавальному барабані.

Виклад основного матеріалу. Для забезпечення обробки деталей за один прохід та необхідної точності обробки, при великосерійному та масовому виробництві використовується спосіб шліфування орієнтованими кругами $з$ 
TECHNICAL SCIENCES AND TECHNOLOGIES

калібруючими ділянками з одностороннім розташуванням ториів одного діаметра. Калібруючі ділянки при цььому робляться різної довжини, залежно від діаметра, відповідно більшого та меншого.

Висновки відповідно до статmі. Запропонована універсальна методика практичного використання моделі точності формоутворення ториів деталей різних діаметрів, орієнтованими шліфуввальними кругами з калібруючими ділянками та без них. Представлений спосіб спрощує правку шліфувального круга. Не потребує спеціальної правки, дозволяє використовувати штатну правку.

Ключові слова: шліфування; кінці різних діаметрів; штовхачі; орієнтовані шліфувальні круги; калібрувальні секції.

Рис.: 3. Бібл.: 10

УДК 621.923

\section{Александр Литвин, Дмитрий Кальченко \\ ИССЛЕДОВАНИЕ ПРОЦЕССА ДВУХСТОРОННЕГО ШЛИФОВАНИЯ ТОРЦОВ ТОЛКАТЕЛЕЙ РАЗНОГО ДИАМЕТРА}

Актуальность темы исследования. В станкостроении, автомобилестроении, сельскохозяйственном машиностроении, производствах, где необходимо обеспечение высокой точности поверхностей деталей с различными диаметрами ториов, нужно придерживаться высоких требований к качеству, предъявляемых к геометрических размеров, шероховатости и точности формообразования.

Постановка проблемы. Шлифовка ториевых поверхностей деталей с различными диаметрами ториов, осуществляются на двусторонних ториешлифовальных станках. Удельный вес илифования в общей трудоемкости механической обработки постоянно растет и на современном этапе составляет в станкостроительной промышленности около $30 \%$, в автомобильной промышленности более 38 \% общей трудоемкости обработки.

Анализ последних исследований и публикаций. На двусторонних ториешлифовальных станках фирмы Saturn (Германия) выполняется обработка кругльх ториов деталей с круговой подачей в зону обработки. Используются абразивные круги без калибруюших участков, требует многопроходную обработку для получения необходимой точности, что снижает производительность илифования. Недостатком способа является то, что не рассматривается обработка деталей с разными диаметрами ториов.

Выделение неисследованных частей общей проблемы. Необходимо провести повышение эффективности обработки деталей, благодаря совершенствованию способов двустороннего шлифовки ториов толкателей с различными диаметрами ориентированными профилированными шилифовальными кругами с калибровкой участками и без них, а также вращения ли вращения обрабатывающей детали на калибровкой участке, не менее одного оборота.

Постановка задачи. Повышение точности обработки конечных поверхностей деталей разного диаметра с шлифовальными кругами достигается тем, что формирование конщов меньшего диаметра осуществляется с помощью максимального диаметра плоского кониа одного круга, а формирование ториевая поверхность большего диаметра - калибровочная секция второго круга, длина которой равна диаметру большего конца и наполнена алмазным карандамом, который движется вдоль радиуса, который совпадает с радиусом расположения оси частей в подающем барабане.

Изложение основного материала. Для обеспечения обработки деталей за один проход и требуемой точности обработки, при крупносерийном и массовом производстве используется способ шллифовки ориентированными кругами с калибровкой участками с односторонним расположением ториов одного диаметра. Калибровкой участка при этом делаются различной длины, в зависимости от диаметра, соответственно большего и меньшего.

Выводы в соответствии со статьей. Предложенная универсальная методика практического использования модели точности формообразования ториов деталей различных диаметров, ориентированными шллиовальными кругами с калибровкой участками и без них. Представленный способ упрощает правку шлифовального круга. Не требует специальной правки, позволяет использовать итатную правку.

Ключевые слова: илифовка; конце различных диаметров; толкатели; ориентированы илифовальные круги; калибровочные секиии.

Рис.: 3. Библ.: 10.

Lytvyn Oleksandr - PhD student of the Department of Information Technologies and Software Engineering, Chernihiv National University of Technology (95 Shevchenka Str., 14035 Chernihiv, Ukraine).

Литвин Олександр Олександрович - аспірант кафедри інформаційних технологій та програмної інженерії, Чернігівський національний технологічний університет (вул. Шевченка, 95, м. Чернігів, 14035, Україна).

Литвин Александр Александрович - аспирант кафедры информационных технологий и программной инженерии, Черниговский национальный технологический университет (ул. Шевченко, 95, г. Чернигов, 14035, Украина).

E-mail: xpower4718@gmail.com

ORCID: http://orcid.org/0000-0002-5243-3970

ResearcherID: J-1479-2016

Kalchenko Dmytro - master, Chernihiv National University of Technology (95 Shevchenka Str., 14035 Chernihiv, Ukraine).

Кальченко Дмитро Володимирович - магістр, Чернігівський національний технологічний університет (вул. Шевченка, 95, м. Чернігів, 14035, Україна).

Кальченко Дмитрий Владимирович - магистр, Черниговский национальный технологический университет (ул. Шевченко, 95, г. Чернигов, 14035, Украина).

E-mail: itmia@ukr.net

Lytvyn, O., Kalchenko, D. (2018). Investigation of the process of double-sided grinding of torches of pushers with different diametrers. Technical sciences and technologies, 2 (12), 86-93. 